\title{
PIK3CA Gene Mutations in Solid Malignancies: Association with Clinicopathological Parameters and Prognosis
}

\author{
Ali Alqahtani ${ }^{1, *}$, Hazem S. K. Ayesh ${ }^{1}$ and Hafez Halawani ${ }^{2}$ \\ 1 Department of Internal Medicine, University of Toledo College of Medicine and Life Sciences, Toledo, \\ OH 43614, USA; Hazem.Ayesh@utoledo.edu \\ 2 Department of Oncology, Cabrini Cancer Center, Alexandria, LA 71301, USA; Halhalawani@gmail.com \\ * Correspondence: Ali.Alqahtani3@utoledo.edu
}

Received: 3 November 2019; Accepted: 19 December 2019; Published: 30 December 2019

\begin{abstract}
Phosphoinositide kinases (PIKs) are a group of lipid kinases that are important upstream activators of various significant signaling pathways. Hyperactivation of the PI3K/AKT/mTOR pathways - either via mutations or genomic amplification-confers key oncogenic activity, essential for the development and progression of several solid tumors. Alterations in the PIK3CA gene are associated with poor prognosis of solid malignancies. Although the literature reports contradictory prognostic values of PIK3CA in aggressive cancers, most of the available data highlight the important role of PIK3CA mutation in mediating tumorigenesis via increased signaling of the PI3K/AKT/mTOR survival pathway. Several inhibitors of PI3K/AKT/mTOR pathways are investigated as potential therapeutic options in solid malignancies. This article reviews the role of PIK3CA mutations and inhibitors of PI3K/AKT/mTOR pathways in major cancer types and examines its association with clinicopathological parameters and prognosis.
\end{abstract}

Keywords: solid malignancy; PIK3CA; mutation; overall survival; PI3K/AKT/mTOR pathway

\section{Introduction}

Phosphoinositide kinases (PIKs) are a group of lipid kinases that act as signal transducers in various signaling pathways. They mediate signaling by phosphorylating the inositol ring of phosphoinositides.

PIKs are classified into three major families depending on the site of phosphorylation on the carbohydrate: phosphoinositide 3-kinases (PI3Ks), phosphoinositide 4-kinases (PIP4Ks), and phosphoinositide 5-kinases (PIP5Ks). PI3Ks are heterodimeric enzymes composed of catalytic and regulatory subunits. They can be categorized into classes I, II, or III, depending on the substrate specificity and their subunit structure and regulation.

PI3K is activated by a growth factor bound receptor tyrosine kinase (RTK), and once activated, it phosphorylates other signaling molecules, in a substrate specific manner, resulting in downstream conduction of chemical signals. Specifically, the activated PI3K generates the second messenger, phosphatidylinositol 3,4,5-trisphosphate (PIP3), by phosphorylating phosphatidylinositol 4,5 bisphosphate (PIP2). The activation of PI3K and subsequent production of PIP3 mediates various downstream pathways involved in several cellular functions including the pathways of tumor development and progression. PI3K signaling plays pivotal roles in cellular processes including cell proliferation, migration, transport within the cells and, most importantly, cell survival (Figure 1). 


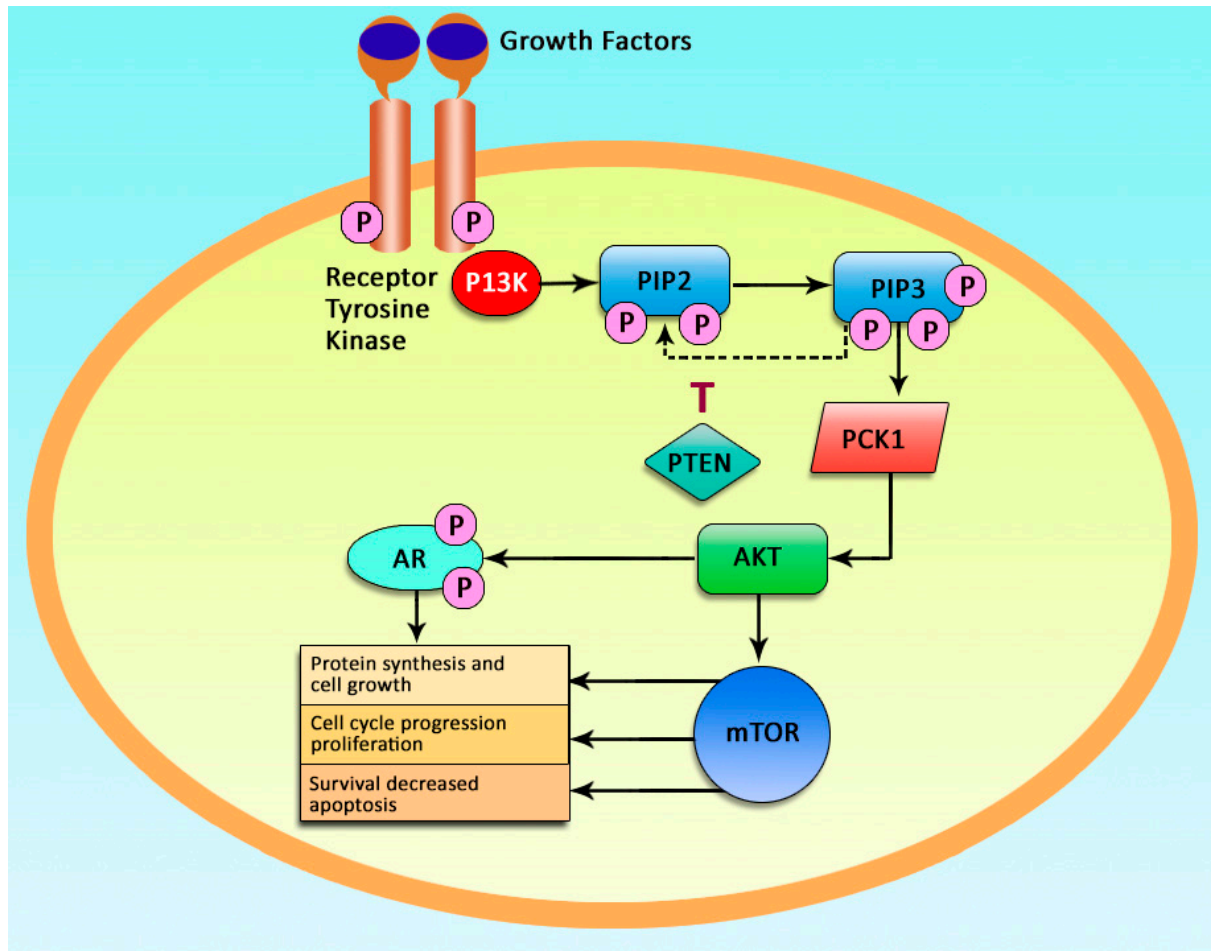

Figure 1. The phosphatidylinositol 3-kinase (PI3K)/AKT/mTOR pathway. Main signaling pathway initiated by growth factors that activate tyrosine kinase to initiate a series of downstream reactions that trigger P13K to generate second messenger (PIP3). PIP3 activates downstream signaling cascade important in cell proliferation, migration, transport, and survival.

The phosphatidylinositol-4,5-bisphosphate 3-kinase catalytic subunit alpha (PIK3CA) gene encodes the $\mathrm{p} 110 \alpha$ protein, the catalytic subunit of PI3K. The present review discusses the association of mutations in the PIK3CA p110a catalytic subunit of PI3K due to the increasing reports of the altered protein product of this gene being involved in several human cancer types. PIK3CA is located on chromosome 3q26.3 with a length of $34 \mathrm{~kb}$. It has 20 exons that code for a protein of $124 \mathrm{kDa}$ consisting of 1068 amino acids. Gene insertions, deletions, and somatic missense mutations in this gene have been reported in many human cancer types, like colon, breast, brain, liver, stomach, and lung cancers. Somatic mutations in PIK3CA were proposed to increase its kinase activity, resulting in cellular transformation [1].

In the year 1991, Graziani et al. were the first to show the association of PI3Ks, especially its subunit $\mathrm{p} 110 \alpha$, with cancer. They also showed that the kinase activity of PI3K was associated with viral oncoproteins [2]. This observation was further supported by reports of avian and murine retroviruses encoding oncogenic derivatives of the cellular PIK3CA and AKT genes, respectively [3,4].

Further investigations showed that phosphatase and tensin homolog (PTEN) dephosphorylates the 3-position on inositol head groups and, thereby, reverses the reaction catalyzed by PI3Ks. PTEN was observed to be a tumor suppressor gene that is found mutated in the common human tumors $[5,6]$. In these tumors, the PTEN mutation results in the constitutive activation of the PI3K pathway.

Several other studies reported the amplification of genomic regions containing AKT, PDPK1, or PIK3CA genes $[7,8]$ in various cancer types. This implied that PI3K acted as an oncogene. Mutations in the regulatory subunit of PI3K (p85) have been reported in ovarian and colon cancers [9]. A recent study demonstrated 13\% mutational frequency of PIK3CA in solid tumors [10]. These observations substantiated the involvement of PI3K signaling in various cancer types. The present review article discussed the role of PIK3CA mutations in various types of solid malignancies in terms of prevalence, potential correlation with clinicopathological parameters, and role in PI3K-targeted inhibition. 


\subsection{PIK3CA Mutations in Breast Cancer}

Missense mutations in PIK3CA are commonly found in several types of breast cancers. The main hot spots of oncogenic mutations were exon 9 and 20, which code for kinase and helical domains of the enzyme and result in overactivation of this protein [11].

The PIK3CA mutations in breast cancer were initially reported by Samuels et al. [12]. In their study, only one out of 12 patients had mutation in PIK3CA [12]. This report instigated other research groups to comprehensively carry mutational analysis of $P I K 3 C A$ in breast cancers $[13,14]$. In a very short span of time, several mutations in PIK3CA were discovered, making it the most frequently mutated oncogene in breast cancer. It is now believed that mutations of PIK3CA are found in 20-30\% of all human breast cancers $[13,14]$.

Several studies have evaluated the correlation of PIK3CA mutations with clinicopathological parameters such as estrogen receptor (ER)/progesterone receptor (PR) positivity, the presence of lymph node metastases, and response to therapy in breast cancers (Table 1).

Table 1. Association of PIK3CA mutation with clino-pathological and prognostic parameters.

\begin{tabular}{|c|c|c|}
\hline Cancer Type & Reference & Clinicopathological and Prognostic Parameters \\
\hline \multirow{8}{*}{ Colon Cancer } & [15] & Nodal metastases, high pathological TNM stage, and lymphatic invasion \\
\hline & [16] & Decreased risk of peritoneal metastases \\
\hline & {$[17,18]$} & Diffuse-type and poorly differentiated gastric cancers and peritoneal recurrence \\
\hline & {$[17,10]$} & Not associated with patient outcomes such as survival \\
\hline & {$[19,20]$} & Not associated with the overall survival \\
\hline & [21] & Increased five-year relapse-free interval \\
\hline & {$[22,23]$} & Against anti-EGFR antibodies \\
\hline & [24] & Poor prognosis \\
\hline \multirow{11}{*}{ Breast Cancer } & [14] & Nodal involvement \\
\hline & [25] & Hormone receptor positive and HER2-positive status \\
\hline & {$[26,27]$} & $\begin{array}{l}\text { ER-positive, PR-positive, low Ki } 67 \text { labeling index and negatively correlated with } \\
\text { triple-negative breast cancer subtype }\end{array}$ \\
\hline & {$[28,29]$} & Poor survival rates \\
\hline & [30] & $\begin{array}{l}\text { Mutations in exon } 9 \text { are associated with poor prognosis but mutations in exon } 20 \\
\text { are associated with better prognosis }\end{array}$ \\
\hline & [31] & Reduced disease-free survival \\
\hline & [32] & Risk factors for progression-free survival \\
\hline & [33] & Poor survival \\
\hline & [34-37] & Better survival \\
\hline & {$[30]$} & $\begin{array}{l}\text { Exon } 9 \text { mutations are independently associated with early recurrence and death, } \\
\text { whereas exon } 20 \text { PIK3CA mutations are associated with optimal prognosis }\end{array}$ \\
\hline & [38-41] & Resistant to antibody-based therapeutic therapy and chemotherapy \\
\hline
\end{tabular}

Saal et al. were the first to report a definite clinicopathological correlate of PIK3CA mutations in breast cancer [14]. They reported that PIK3CA mutations were frequently seen in tumors with normally expressed PTEN, ER, PR, and ERBB2 genes, as well as in tumors with nodal involvement. Studies demonstrated that mutations in PIK3CA were more common in hormone receptor-positive and HER2-positive breast cancers [25]. In a recent study by Wu et al., it was shown that PIK3CA mutations were positively associated with ER-positive, PR-positive, and low Ki67 labeling index, and negatively correlated with the triple-negative breast cancer subtype [26]. PIK3CA mutations were not associated with age at diagnosis, tumor stage, lymph node status, tumor size, or HER2 status [26].

Various contradictory studies exist regarding the effect of PIK3CA mutation status on disease prognosis; PIK3CA mutations were reported to be correlated with poor survival rates [28,29].

Barbareschi et al. reported different effects based on mutation loci. They reported that those in exon 9 are associated with poor prognosis, while those occurring in exon 20 are associated with better prognosis [30].

Deng et al. demonstrated that PIK3CA mutation significantly reduced disease-free survival (DFS) compared to wild-type (WT) PIK3CA in patients with ER-positive tumors [31]. Subsequent studies 
reported that PIK3CA mutations were highly associated with the morphology, race, ER status, PR status, and HER2 status in breast cancer [27]. Seo et al. substantiated this observation reporting similar findings [37]. PIK3CA mutations were predicted to be risk factors for shorter progression-free survival (PFS) [32]. Recently, co-mutation of TP53 and PIK3CA was found to be associated with poor survival in residual disease after neoadjuvant chemotherapy in breast cancer [33]. Contrary to these findings, a few reports also suggested that PIK3CA mutations are associated with better survival [34-36]. In addition, studies have reported exon 9 mutations are independently associated with early recurrence and death, whereas exon 20 PIK3CA mutations are associated with optimal prognosis [29].

A contradictory report highlighted that there is no association of PIK3CA mutation status with a prognosis of breast cancer [26].

Another important clinicopathological correlate of PIK3CA mutation is that they are more frequently found in lobular breast cancers as compared to ductal breast cancers [42]. Barbareschi et al. reported that this observation was specific for patients with exon 9 mutations [30].

PIK3CA mutations have also been correlated with response to therapy in breast cancer. Berns et al. reported that mutations in PIK3CA make breast cancers resistant to antibody-based therapeutic trastuzumab [38]. Eichhorn et al. have suggested that over activation of PIK3CA due to oncogenic mutations rendered breast cancer cells refractive to the anti-HER2 agent Lapatinib [40]. PIK3CA mutations were shown to reduce sensitivity to neoadjuvant chemotherapy $[37,41]$.

Contrary to these findings, Liedtke et al. found no association between PIK3CA mutations and a response to anthracyline and paclitaxel-based chemotherapy [43]. Activation of the PI3K/AKT/mTOR signaling pathway contributed to the resistance to endocrine therapy in breast cancers [44]. Mutations in the PIK3CA have been reported to be associated with resistance to several antitumor agents such as paclitaxel, tamoxifen, and trastuzumab [45]. It has been shown that PI3K and ER pathways have a synergistic effect on tumor progression [46]. Recently, it was shown that Everolimus treatment along with chemotherapy suppressed PIK3CA, ESR1, and GATA3 gene mutation [47].

\subsection{Prognostic Importance of PIK3CA Genetic Mutations in Colorectal Cancer}

The initial study on the involvement of PIK3CA mutation in colorectal cancer was reported by Samuels et al., who showed that whole-genome sequencing of colon tumors revealed a PIK3CA mutation frequency of 32\% [12]. A recent study reported PIK3CA mutation frequency of $14 \%$ in Belgian colorectal cancer patients. Another recent study on Chinese colon cancer patients reported a mutation frequency of $18.94 \%$, and these mutations were more prevalent in the right-side colorectal cancer [48]. Another study also supported this finding but showed no correlation of PIK3CA gene mutations with clinical parameters such as gender, age, cancer stage, or differentiation [49]. PIK3CA mutations were reported to be more prevalent in the "protruded-type" of colon cancer as compared to the "flat-type" colon cancers [50]. Family history or inherited predisposition did not have any effect on the frequency of PIK3CA gene mutations in colorectal cancer. However, the patients with inherited predisposition had mutations in the kinase domain, whereas the sporadic cases had mutations in the helical domain of the gene [51]. The mutational frequency of PIK3CA in colon cancers shows gender bias with more frequency in the females as compared to the males [15]. However, a recent study did not find any significant difference between male and female colon cancer patients with respect to frequency of PIK3CA mutations [16].

Several studies attempted to establish a correlation between PIK3CA gene mutations and clinicopathological parameters like survival and response to therapy. All the cases with PIK3CA mutations in poorly differentiated clusters had nodal metastases, high pathological TNM stage, and lymphatic invasion [52]. A recent study highlighted that PIK3CA mutation is associated with decreased risk of peritoneal metastases in metastatic colorectal cancer [24]. Similar to breast cancer, the effect of PIK3CA mutational status on prognostic outcome remains controversial. In many studies, PIK3CA gene mutations have been correlated with poor prognosis [22,23,53,54]. 
Similarly, PIK3CA amplifications were associated with the occurrence of diffuse-type and poorly differentiated gastric cancers and peritoneal recurrence as compared to those without PIK3CA amplifications. It was also demonstrated that PIK3CA mutations conferred resistance to colon cancer cells against anti-EGFR antibodies [17,18].

However, other studies failed to establish an association between the PIK3CA amplifications or mutations, and patient outcomes such as survival [19-21,55]. Furthermore, another study even reported PIK3CA mutation to be associated with good prognosis in patients with microsatellite stability (MSS) stage I-III colon cancer with a significantly increased five-year relapse-free interval in patients with PIK3CA-mutated MSS tumors vs. those with PIK3CA WT MSS tumors [56].

Interestingly, recent clinical trials have strongly highlighted that low-dose aspirin (100 mg/day) can act as therapy in colorectal cancer patients positive for PIK3CA mutations and who have undergone surgical resection in terms of reducing the risk of recurrence $[57,58]$.

\subsection{Prognostic Role of PIK3CA Gene Mutation in Lung Cancer}

PIK3CA gene amplifications have been reported in lung cancer $[59,60]$. The frequency of PIK3CA gene mutation in lung cancer varies significantly. Samuels et al. reported a low frequency of PIK3CA mutations $(4 \%)$ in lung cancer $[12,61,62]$, with higher frequency seen in squamous cell carcinoma $(7 \%)$ as compared to adenocarcinoma ( $2 \%)$. Another study involving more than 700 lung cancer samples reported the PIK3CA mutation frequency to be ca. 2\% [63]. Kawano et al., for the first time, reported the amplification of mutant PIK3CA alleles in cancer cells [64]. PI3K pathway alterations have been identified in over $50 \%$ of lung squamous cell carcinoma cases [65]. However, a recent study in young lung adenocarcinoma patients demonstrated the absence of PIK3CA gene mutations [66]. A mutation frequency of $5.36 \%$ has been reported in non-small cell lung cancer [67]. The frequency of PIK3CA gene mutations was higher in metastatic lung adenocarcinoma than in primary tumors [68].

PIK3CA mutation was significantly associated with higher risk of lung failure in patients undergoing lung stereotactic body radiation therapy [69].

PIK3CA mutations were reported to be associated with invasive growth, vacuolar signs, and margin lobulation on chest CT. PIK3CA gene mutations were shown to be associated with metastases, poor prognosis, and shorter PFS times [70].

\subsection{The Role of PIK3CA Gene Mutations in Thyroid Cancer}

Contradictory findings are reported in the literature regarding the role of PIK3CA gene mutations in thyroid cancers. This may be attributed to the wide variety of different types of thyroid cancer. However, these studies indicate that PIK3CA mutations are prevalent in aplastic thyroid cancer and follicular thyroid cancer as compared to papillary carcinoma of the thyroid [71-73].

In an initial study, PIK3CA mutations were identified in the highest proportion in the anaplastic thyroid carcinomas (16\%), followed by follicular thyroid carcinomas $(8 \%)$, and papillary thyroid carcinomas (2\%) [74]. Subsequent studies have shown varying prevalence of mutation in different subtypes of thyroid cancer, but PIK3CA mutations were the most commonly found in anaplastic cancers and the least observed in papillary. For example, Wang et al. reported the frequency of PIK3CA mutations to be $13 \%$ in follicular thyroid carcinomas and $1 \%$ in papillary thyroid carcinomas [75]. Abubaker et al. reported a $2 \%$ frequency of PIK3CA mutations in papillary thyroid carcinoma [76]. Similarly, Santarpia et al. reported a $14 \%$ frequency of PIK3CA mutations in anaplastic thyroid cancer [77]. This distribution of PIK3CA mutations among thyroid cancer subtypes may raise the valid possibility of it playing a role towards more aggressive cancer development, mirroring the different natural history of anaplastic (most aggressive) vs. papillary thyroid cancer (least aggressive).

However, subsequent studies reported that PIK3CA mutations played no role in these thyroid tumor types. These studies rather highlighted the involvement of PIK3CA gene amplification in thyroid cancer development [78,79]. Another study reported that there is no involvement of PIK3CA mutations in pediatric thyroid cancer [80]. 
PIK3CA mutations have been reported to co-occur with other mutations and aberrations of relevance: for example, Xing et al. reported a protective effect of SNP rs17849071 of PIK3CA gene in follicular thyroid cancer [81]. BRAF and PIK3CA mutations cooperatively promoted anaplastic thyroid cancer [82]. Additionally, in cooperation with KRAS mutations, PIK3CA mutations were reported to be associated with metastasis in thyroid cancer. These, however, did not correlate with any of the clinicopathological parameters or prognostic parameters studied, with no effect on PFS.

Studies conducted to elucidate the role of PIK3CA mutations in the clinicopathological parameters and prognosis point that these mutations have minimal association with the prognosis of thyroid cancers [83]. However, the presence of PIK3CA mutation, along with other activating mutations, resulted in increased rates of mortality and aggressive metastasis [84].

\subsection{PIK3CA Gene Mutations Frequency in Head and Neck Squamous Cell Cancer (HNSCC)}

PIK3CA gene mutations are frequently observed in head and neck carcinoma. An initial study reported PIK3CA mutational frequency of $11 \%$ in squamous cell carcinoma in pharyngeal cancer samples [85]. The same group further reported a higher frequency (21\%) of PIK3CA mutation in tumors of mixed origin [85]. The mutational frequency of PIK3CA varied between types of HNSCC: oral squamous cell carcinomas (OSCC: $21 \%$ in cell lines and $17 \%$ in of primary tumors) [86]; nasopharyngeal carcinomas (10\%; [87]); and head and neck cancer cell lines (30\%; [88]). PIK3CA gene amplifications were also reported in oral cavity cancer cell lines [89].

HNSCC patients were reported to harbor PIK3CA mutations at even higher frequency, with a mutational frequency of 31\% [90]. In salivary duct carcinoma (SDC), the mutation frequency of PIK3CA was shown to be $28 \%$ [91]. Targeted next generation sequencing revealed a mutation rate of $7.5 \%$ in OSCCs [92]. Novel mutations in PIK3CA were recently reported as candidate driver events in human papillomavirus (HPV)-positive OSCCs [93].

In terms of prognostication, Chou et al. reported that there was no significant relationship of PIK3CA mutational status with clinicopathological characteristics of the tumors [94]. However, differential response of PIK3CA-mutated vs. WT tumors, to PI3K-targeted therapies, remains controversial in HNSCC. While one study revealed no association between PIK3CA and responsiveness to PI3K-targeted drugs [94], another group reported PIK3CA mutations to be associated with potential benefit from matched targeted therapy in parathyroid carcinoma [95]. In a recent study evaluating the effect of nonsteroidal anti-inflammatory drugs (NSAID) on survival in head and neck cancer, patients with PIK3CA mutations or amplification showed prolonged disease-specific survival and overall survival with NSAID use as compared with non-NSAID users [96]. Mutations in PIK3CA gene were associated with improved outcomes among metastatic HPV-positive oropharyngeal cancer [97], with similar results reported in HPV-negative oropharyngeal cancer [98]. Moreover, the combination of temsirolimus, carboplatin, and paclitaxel resulted in tumor regression in head and neck squamous cell carcinomas [99].

\subsection{Prognostic Role of PIK3CA Gene Mutations in Esophageal Cancer}

Initial reports of PIK3CA gene mutations in esophageal cancers demonstrated that these mutations were present in $12 \%$ of squamous cell carcinomas and $6 \%$ of adenocarcinomas of the esophagus. In contrast, Akagi et al. showed no involvement of PIK3CA mutations in esophageal squamous cell carcinoma [100]. Recently, PIK3CA mutations were identified in $21.7 \%$ of chagasic megaesophagus associated with esophageal squamous cell carcinoma cases. This study also highlighted that these mutations were associated with lower survival rates [101]. In $48 \%$ of esophageal squamous cell neoplasia, PIK3CA was identified to be amplified [102]. It was recently shown that PIK3CA is the most frequently mutated gene in esophageal sarcomatoid carcinoma [103], similar to what has been described for HNSCC. A meta-analysis showed that PIK3CA mutation has no significant effects on overall survival and disease-free survival in esophageal squamous cell carcinoma [104]. However, patients with PIK3CA gene mutations in exon 9 have better disease-free survival and overall survival 
rates [105]. Yokota et al. showed that PIK3CA gene mutations are independent favorable prognostic marker in esophageal cancer patients in terms of survival [106].

\subsection{The Importance of PIK3CA Gene Mutations in Pathogenesis of Renal Cell Cancer}

The PI3K/AKT/mTOR pathway is altered in approximately $20 \%$ cases, by mutations in PIK3CA gene [107]. Next generation sequencing revealed the presence of PIK3CA gene mutations in RCC [108] but not in the clear cell subtype (cc-RCC), which is the major and most deadly RCC [109]. However, in a study that focused on cc-RCC, 20 components of the PI3K/AKT/mTOR pathway were analyzed by sequencing. In this study, PIK3CA amplifications or mutations were reported at $5 \%$ and were mutually exclusive with the other 19 components of the pathway.

PIK3CA mutations have also been reported in nephroblastomatosis or Wilms tumor [110].

\subsection{Association of PIK3CA Genetic Mutations with Cervical, Ovarian, and Urothelial Cancer}

PIK3CA mutations have been reported in urothelial papilloma cases [111]. PIK3CA gene amplification has been observed in recurrent ovarian cancer [112] and yolk sac tumors [113]. In addition, PIK3CA mutation was identified in 38\% endometrial cancer samples [114]. Amplification of PIK3CA has been associated with pathogenesis of cervical cancer. Miyaki et al. reported PIK3CA mutations in 14\% invasive cervical carcinomas, while Cui et al. reported these mutations in $8.15 \%$ of invasive cervical carcinomas [50,115]. PIK3CA gene mutation has also been identified in small cell carcinoma of cervix [116].

A recent study in cervical cancer showed that PIK3CA mutation status did not have any significant association with clinicopathological characteristics but highlighted an association with poor overall survival [117]. Somatic mutations in PIK3CA have been reported in low frequencies in Vulvar squamous cell carcinoma [118]. PIK3CA mutations were observed in 10\% of bladder cancer patients [119] and are associated with cisplatin resistance and a migratory phenotype in cervical cancer cells [120].

\section{PI3K Inhibitors}

As discussed earlier, the PI3K/AKT/mTOR pathway plays a pivotal key role in solid malignancies. In addition, several PI3K inhibitors have been effectively tested in various cancer types. A recent meta-analysis involving 46 different randomized control trials highlighted that the supplementation of therapy with PI3K inhibitors significantly improved progression-free survival [121]. Hyperactivation of PI3K signaling is a hallmark of cancer, and activating mutations in this pathway are common in solid malignancies [122].

Preclinical tests have demonstrated that cancer cell lines derived from solid cancers became sensitive to hormone therapy, chemotherapy, or other targeted therapies when they are treated with PI3K or mTOR inhibitors [123].

The PI3K/AKT/mTOR pathway inhibitors were found to be effective in improving progression-free survival in patients with PI3K pathway mutations [121]. Table 2 summarizes different clinical trials focused on PI3K/AKT/mTOR pathway inhibitors. In the same meta-analysis it was found that these inhibitors improved overall survival in breast cancer, renal cancer, gastrointestinal cancer, head and neck squamous cell cancer, pancreatic cancer, neuroendocrine tumor and sarcomas. However, this improvement was not statistically significant and did not show any significant effect on the overall survival in other types of cancers [121].

In the year 1988, PI3K (phosphoinositide3-kinase) was first identified as a signal transducer for cell surface growth factor receptors [124]. It is one of the most commonly implicated signal pathways in a number of cancers. Although PI3K mutations were thought to be associated with oncogenesis, it was only in the year 2004, its contributory role in cancer has been established unequivocally [124]. Genetic hyperactivity of the PI3K/AKT pathway has been established as one of the most recognized underlying mechanisms for a number of cancers [124,125]. Table 3 shows a list of clinical trials that highlighted the role of mTOR and PI3K inhibitors in solid and hematological tumors therapy. 
Table 2. Different PI3K/AKT/mTOR inhibitors under clinical development or approved for clinical use in SOLID tumors.

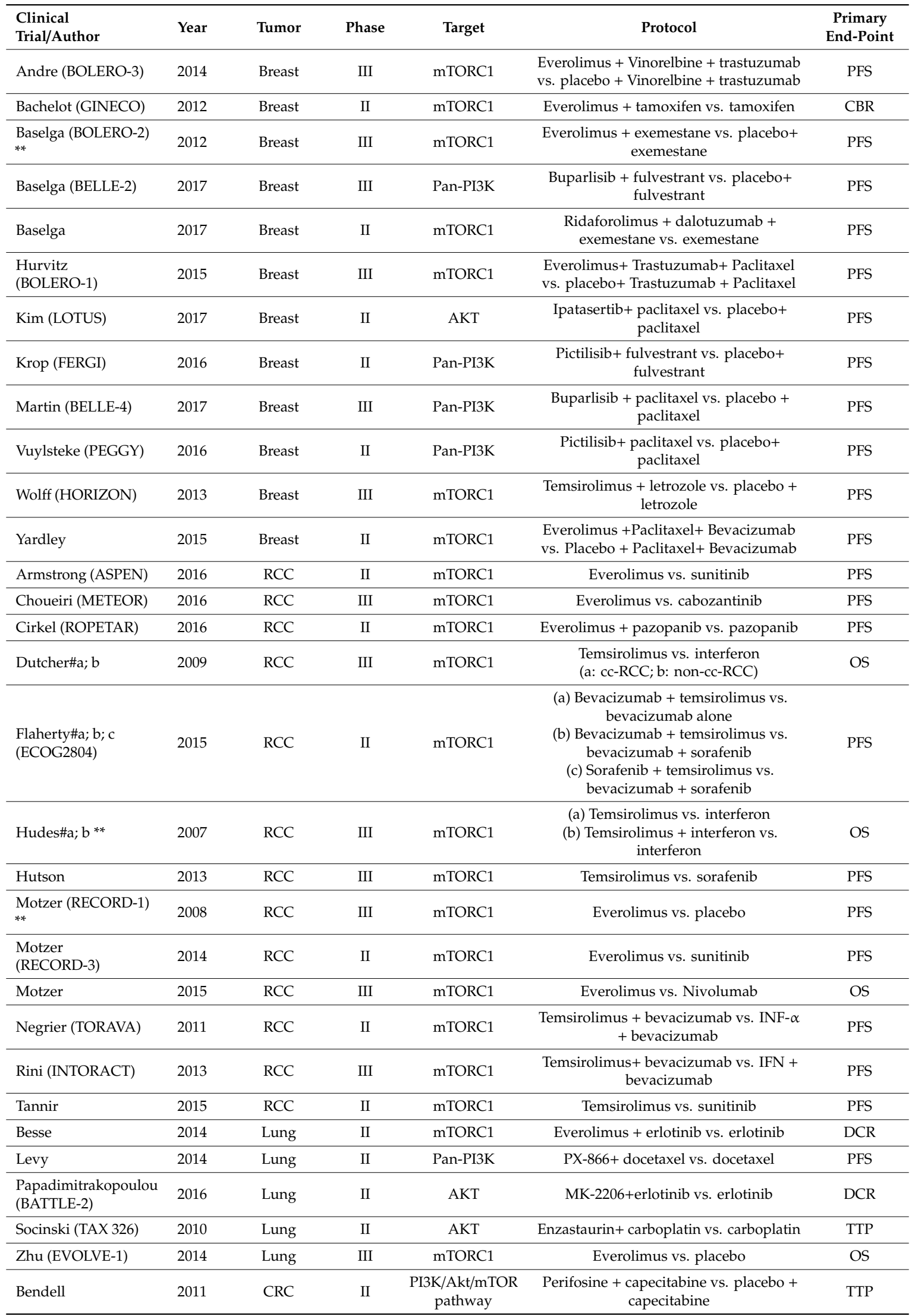


Table 2. Cont.

\begin{tabular}{|c|c|c|c|c|c|c|}
\hline Bowles & 2016 & CRC & II & Pan-PI3K & $\begin{array}{c}\text { PX-866 + cetuximab vs. placebo }+ \\
\text { cetuximab }\end{array}$ & PFS \\
\hline Ohtsu (GRANITE-1) & 2013 & $\begin{array}{l}\text { Gastric } \\
\text { cancer }\end{array}$ & III & mTORC1 & Everolimus vs. placebo & OS \\
\hline Jimeno & 2015 & HNSCC & II & Pan-PI3K & PX-866 + cetuximab vs. cetuximab & PFS \\
\hline Jimeno & 2016 & HNSCC & II & Pan-PI3K & PX-866 + docetaxel vs. docetaxel & PFS \\
\hline Rachards & 2011 & Pancreatic & II & AKT & $\begin{array}{l}\text { Enzastaurin }+ \text { gemcitabine vs } \\
\text { gemcitabine }\end{array}$ & OS \\
\hline Pavel (RADIANT-2) & 2011 & NET & III & mTORC1 & $\begin{array}{l}\text { Everolimus + octreotide LAR vs } \\
\text { placebo+ octreotide LAR }\end{array}$ & PFS \\
\hline Yao (RADIANT-3) ** & 2011 & NET & III & mTORC1 & Everolimus vs. placebo & PFS \\
\hline Demetri & 2013 & Sarcoma & III & mTORC1 & Redaforolimus vs. placebo & PFS \\
\hline Oza & 2015 & $\begin{array}{l}\text { Endometrial } \\
\text { cancer }\end{array}$ & II & mTORC1 & $\begin{array}{l}\text { Ridaforolimusvs progestin or } \\
\text { chemotherapy }\end{array}$ & PFS \\
\hline $\begin{array}{l}\text { Wick (EORTC } \\
\text { 26082) }\end{array}$ & 2016 & Glioblastoma & II & mTORC1 & Temsirolimus vs. temozolomide & OS \\
\hline Margolin (S0438) & 2012 & Melanoma & II & mTORC1 & $\begin{array}{c}\text { Temsirolimus }+ \text { sorafenib vs. tipifarnib }+ \\
\text { sorafenib }\end{array}$ & PFS \\
\hline
\end{tabular}

**: Trials leading to product FDA approval; PFS: Progression-free survival; OS: Overall survival; IFN: interferon; TTP: Time to progression; CBR: Clinical benefit rate; DCR: Disease control rate; mTORC1: Mammalian target of rapamycin complex1; RCC: Renal cell carcinoma; cc-RCC: Clear cell-RCC; NET: Neuroendocrine tumor; HNSCC: Head and neck squamous cell carcinoma; CRC: Colorectal cancer.

Table 3. Clinical trials that lead to mTOR and PI3K inhibitors in solid and hematological tumors.

\begin{tabular}{|c|c|c|c|c|c|}
\hline Biomarker & Drug & Target & Population & $\begin{array}{l}\text { Study } \\
\text { Phase }\end{array}$ & $\begin{array}{c}\text { Clinicaltrials.gov } \\
\text { Registration }\end{array}$ \\
\hline $\begin{array}{l}\text { PIK3CA mutation or } \\
\text { amplification }\end{array}$ & Sirolimus & mTROC1 & $\begin{array}{c}\text { Advanced-stage solid } \\
\text { cancers }\end{array}$ & II & NCT02449564 \\
\hline $\begin{array}{l}\text { PIK3CA mutation or } \\
\text { amplification or PTEN loss }\end{array}$ & Copanlisib & Pan-PI3K & Advanced HNSCC & $\mathrm{I} / \mathrm{II}$ & NCT02822482 \\
\hline \multirow[t]{3}{*}{ PIK3CA mutation } & $\begin{array}{l}\text { Alpelisib + } \\
\text { fulvestrant }\end{array}$ & PI3K- $\alpha$ & $\begin{array}{c}\text { Advanced-stage } \\
\text { HR+/HER2- breast cancer }\end{array}$ & III & NCT02437318 \\
\hline & $\begin{aligned} & \text { Alpelisib } \\
&+ \text { fulvestrant } \\
& \pm \text { letrozole }\end{aligned}$ & PI3K- $\alpha$ & $\begin{array}{c}\text { Advanced-stage } \\
\text { HR+/HER2- breast cancer }\end{array}$ & II & NCT03056755 \\
\hline & Taselisib & PI3K- $\alpha$ & $\begin{array}{c}\text { Advanced-stage SCC of } \\
\text { the lung }\end{array}$ & II & NCT02154490 \\
\hline \multirow{3}{*}{$\begin{array}{l}\text { PIK3CA and/or BRAF } \\
\text { mutations } \\
\text { PIK3CA, AKT, or PTEN } \\
\text { mutations }\end{array}$} & ASN003 & $\begin{array}{c}\text { PI3K- } \alpha \text { AND } \\
\text { BRAF }\end{array}$ & $\begin{array}{l}\text { Advanced-stage solid } \\
\text { cancers }\end{array}$ & I & NCT02961283 \\
\hline & MK-2206 & $\mathrm{AKT}$ & $\begin{array}{l}\text { Advanced-stage lung and } \\
\text { thymus cancers }\end{array}$ & II & NCT01306045 \\
\hline & $\begin{array}{l}\text { Ipatasertib } \\
+ \text { paclitazel }\end{array}$ & $\mathrm{AKT}$ & $\begin{array}{l}\text { Advanced-stage breast } \\
\text { cancer }\end{array}$ & III & NCT03337724 \\
\hline $\begin{array}{l}\text { PIK3CA mutation or } \\
\text { amplification }\end{array}$ & $\begin{array}{c}\text { AZD5363 } \\
+ \text { paclitaxel }\end{array}$ & $\mathrm{AKT}$ & $\begin{array}{l}\text { Advanced-stage gastric } \\
\text { cancer }\end{array}$ & II & NCT0251956 \\
\hline PIK3CA or $A K T$ mutations & $\begin{array}{l}\text { Miransertib + } \\
\text { carboplatin }\end{array}$ & $\mathrm{AKT}$ & $\begin{array}{l}\text { Selected advanced-stage } \\
\text { solid cancers }\end{array}$ & I & NCT02476955 \\
\hline
\end{tabular}

HR: Hormone receptor.

Literature search reveals that a number of studies have established the role of phosphatidylinositol4,5-bisphosphate 3-kinase, catalytic subunit alpha (PIK3CA) mutations in oncogenesis.

The Cancer Genome Atlas has concluded mutations of PIK3CA as one of the most common genetic events associated with at least 12 different types of solid cancers [126]. Commonly-identified cancers 
of solid tumors associated with PI3K3CA are breast cancer ( $>30 \%$ of total cases), bladder cancer $(>20 \%$ of total cases), colorectal cancer ( $>17 \%$ of total cancer), and squamous cell cancer of head neck region $(>15 \%$ of total cases) [126,127].

In the year 2016, Millis and his colleagues explored the patterns of molecular aberration in the PI3K pathway in relation to solid tumors. From January 2013 to December 2014, 19,784 tumor samples (of more than 40 different types of cancer) sent by thousands of doctors across 60 countries were tested at a single commercial laboratory for molecular profiling to identify genetic and proteomic aberrations in the PI3K pathway [127]. They found around 38\% of the patients had one or more mutations in the PI3K pathway proteins; the most common aberration (30\%) was loss of PTEN (phosphatase and tensin homologue) followed by mutations in PIK3CA (13\%). PIK3CA mutation was associated most commonly with endometrial (37\%), breast (31\%), cervical (29\%), and anal cancers (27\%) [128].

Again, in the year 2013, Kandoth and his colleagues explored the significance and extent of mutation in 12 types of major cancers [127]. They published the results of their analysis regarding mutations (point and small insertions or deletions) in 3281 samples of tumors (of 12 different types of tumors). According to their work PIK3CA was the second most common type of mutation with a frequency of $>10 \%$ in majority of the cancers except ovarian serous carcinoma, renal clear cell cancer, lung adenocarcinoma and acute myeloid leukemia. Most commonly associated cancer varieties with PIK3CA mutation were endometrial cancer (uterine corpus) (52\%) and breast carcinoma (33.6\%).

Discovery of PIK3CA mutations in majority of cancers has led to new targets for treatment of those cancers. Although monotherapy with PIK3CA inhibitors has led to poor response [1], implementation of strategies where PI3K inhibition is tailored as per the cancer type and patients might lead to better response. Table 4 shows selected ongoing clinical trials that involved PIK3CA mutation as a selection population biomarker.

Table 4. Selected ongoing clinical trials of PI3K/AKT/mTOR inhibitors involving PIK3CA mutation as a selection population biomarker.

\begin{tabular}{|c|c|c|c|c|c|c|}
\hline Drug & Target(s) & Trial & Population (n) & Results & $\begin{array}{c}\text { Toxicities } \\
\text { (Most Common) }\end{array}$ & Ref. \\
\hline Temsirolimus & mTORC1 & $\begin{array}{l}\text { Global } \\
\text { ARCC } \\
\text { (vs. INF- } \alpha \text { vs. } \\
\text { combination) }\end{array}$ & $\begin{array}{c}\text { Untreated, mRCC } \\
\quad(n=626)\end{array}$ & $\begin{array}{c}\uparrow \text { OS }(10.9 \text { vs. } 7.3 \text { months; } p=0.008) \\
\uparrow \text { PFS in the temsirolimus } \\
\text { monotherapy }(p<0.001)\end{array}$ & Rash, HG, HL; mild & [5] \\
\hline \multirow[t]{3}{*}{ Everolimus } & mTORC1 & $\begin{array}{l}\text { RECORD-I } \\
\text { (vs. placebo) }\end{array}$ & $\begin{array}{c}\text { Previously treated, } \\
\text { mRCC } \\
(n=272)\end{array}$ & $\begin{array}{c}\uparrow \text { PFS (4.0 vs. } 1.9 \text { months; } p<0.0001) \\
\text { No significant improvement in OS or } \\
\text { in ORR }\end{array}$ & $\begin{array}{c}\text { Stomatitis, rash, } \\
\text { fatigue, pneumonitis, } \\
\text { diarrhea }\end{array}$ & [6] \\
\hline & & $\begin{array}{l}\text { RADIANT-3 } \\
\text { (vs. placebo) }\end{array}$ & $\begin{array}{c}\text { Advanced pancreatic } \\
\text { NET } \\
(n=410)\end{array}$ & $\begin{array}{c}\uparrow \text { PFS (mPFS } 11.0 \text { vs. } 4.6 \text { months; } p< \\
0.001) \\
\text { No clear ORR benefit }\end{array}$ & $\begin{array}{l}\text { Stomatitis, rash, } \\
\text { fatigue, pneumonitis, } \\
\text { diarrhea }\end{array}$ & [7] \\
\hline & & $\begin{array}{l}\text { RADIANT-4 } \\
\text { (vs. placebo) }\end{array}$ & $\begin{array}{l}\text { Other NET } \\
(n=302)\end{array}$ & $\begin{array}{c}\text { ^PFS (11.0 vs. } 3.9 \text { months; } p< \\
0.00001) \\
\text { No clear ORR benefit }\end{array}$ & $\begin{array}{c}\text { Stomatitis, rash, } \\
\text { fatigue, pneumonitis, } \\
\text { diarrhea }\end{array}$ & [8] \\
\hline$+\mathrm{AI}$ & & $\begin{array}{l}\text { BOLERO-2 } \\
\text { (vs. placebo } \\
+\mathrm{AI})\end{array}$ & $\begin{array}{c}\mathrm{HR}+/ \text { HER2 }- \text { breast } \\
\text { cancer } \\
(n=724)\end{array}$ & $\begin{array}{c}\uparrow \uparrow \text { ORR }(9.5 \% \text { vs. } 0.5 \% p<0.001) \\
\uparrow \text { mPFS }(6.9 \text { vs. } 2.8 \text { months; } p<0.001)\end{array}$ & $\begin{array}{c}\text { Stomatitis, rash, } \\
\text { fatigue, pneumonitis, } \\
\text { diarrhea }\end{array}$ & [9] \\
\hline Copanlisib & Pan-PI3K & $\begin{array}{l}\text { CHRONOS-1 } \\
\text { (vs. placebo) }\end{array}$ & $\begin{array}{l}\mathrm{r} / \mathrm{r} \text { B-NHL, } \\
\text { Macroglobulinemia } \\
(n=142)\end{array}$ & $\begin{array}{l}\text { ORR of } 59 \%(12 \% \text { CR and } 47 \% \text { PR), } \\
\text { with a mPFS of } 11.2 \text { months }\end{array}$ & HG, nausea & [12] \\
\hline \multirow[t]{2}{*}{$\begin{array}{c}\text { Idelalisib } \\
+ \text { rituximab }\end{array}$} & PI3K- $\delta$ & $\begin{array}{l}\text { NCT01539512 } \\
\text { (vs. placebo+ } \\
\text { rituximab) }\end{array}$ & $\begin{array}{l}\text { Relapse CLL } \\
\quad(n=220)\end{array}$ & $\begin{array}{c}\text { ORR }(81 \% \text { vs. } 13 \%) \\
\uparrow \text { PFS at } 24 \text { weeks }(93 \% \text { vs. } 46 \% ; p< \\
0.001), \\
\uparrow 1 \text {-year OS }(92 \% \text { vs. } 80 \% ; p=0.002) .\end{array}$ & $\begin{array}{l}\text { Diarrhea, rash, } \\
\text { immune-mediated } \\
\text { hepatitis/ } \\
\text { pneumonis }\end{array}$ & [14] \\
\hline & & $\begin{array}{l}\text { NCT01282424 } \\
\text { (vs. placebo) }\end{array}$ & $\begin{array}{c}\mathrm{r} / \mathrm{r} \text { B-NHL }(\mathrm{FL}) \text { and } \\
\text { SLL } \\
(n=125)\end{array}$ & $\begin{array}{l}\text { ORR: } 54 \% \text { in FL patients and } 58 \% \text { in } \\
\text { SLL }(p<0.001)\end{array}$ & $\begin{array}{l}\text { Diarrhea, rash, } \\
\text { immune-mediated } \\
\text { hepatitis, and } \\
\text { pneumonitis }\end{array}$ & [15] \\
\hline
\end{tabular}

mRCC: Metastatic renal cell carcinoma; OS: Overall survival; PFS: Progression-free survival; mPFS: median PFS; ORR: Objective Response Rate; r/r: Recurrent/relapsed; NET: Neuroendocrine tumors; CLL: Chronic lymphocytic leukemia; SLL: Small lymphocytic leukemia; B-NHL: B-non Hodgkin lymphoma; HR: Hormone receptor; FL: Follicular lymphoma. 
All these studies indicate that PI3K pathway inhibitors in solid malignancies improved progression-free survival in cancer types with PI3K mutations. However, these inhibitors are not significantly effective in improving the overall survival. Considering the side-effects of these therapies, the inhibitors should be used meticulously in treating these cancers.

\section{Conclusions}

PIK3CA gene mutations are clinically important in most solid malignancies. These mutations lead to hyperactivation of the kinase activity of the PI3K pathway, resulting in deregulated cell proliferation. In addition, these mutations have implications in the effectiveness of the treatment and prognosis of cancers. However, contradictory reports exist in the literature regarding the effect of PIK3CA gene mutations on the prognosis of different cancers. Although different clinical trials have successfully reported the usefulness of different Pi3K inhibitors in different solid malignancies and showed a significant positive association with prognostic parameters such as progression-free survival and overall survival. However, larger prospective studies should be conducted to further elucidate the role of PIK3CA mutations in solid malignancies. The advent of high throughput and advanced molecular editing technologies can help evaluate the effectiveness of gene therapies and gene editing using CRISPER/Cas system in correcting genetic defects that result in, or are associated with, poor prognosis of these cancers.

Funding: This research received no external funding.

Conflicts of Interest: The authors declare no conflict of interest.

\section{References}

1. Karakas, B.; Bachman, K.E.; Park, B.H. Mutation of the PIK3CA oncogene in human cancers. Br. J. Cancer 2006, 94, 455-459. [CrossRef] [PubMed]

2. Graziani, A.; Gramaglia, D.; Cantley, L.C.; Comoglio, P.M. The tyrosine-phosphorylated hepatocyte growth factor/scatter factor receptor associates with phosphatidylinositol 3-kinase. J. Biol. Chem. 1991, 266, 22087-22090. [PubMed]

3. Bellacosa, A.; Testa, J.R.; Staal, S.P.; Tsichlis, P.N. A retroviral oncogene, akt, encoding a serine-threonine kinase containing an SH2-like region. Science 1991, 254, 274-277. [CrossRef] [PubMed]

4. Staal, S.P. Molecular cloning of the akt oncogene and its human homologues AKT1 and AKT2: Amplification of AKT1 in a primary human gastric adenocarcinoma. Proc. Natl. Acad. Sci. USA 1987, 84, 5034-5037. [CrossRef] [PubMed]

5. Li, J.; Yen, C.; Liaw, D.; Podsypanina, K.; Bose, S.; Wang, S.I.; Puc, J.; Miliaresis, C.; Rodgers, L.; McCombie, R.; et al. PTEN, a putative protein tyrosine phosphatase gene mutated in human brain, breast, and prostate cancer. Science 1997, 275, 1943-1947. [CrossRef]

6. Steck, P.A.; Pershouse, M.A.; Jasser, S.A.; Yung, W.K.; Lin, H.; Ligon, A.H.; Langford, L.A.; Baumgard, M.L.; Hattier, T.; Davis, T.; et al. Identification of a candidate tumour suppressor gene, MMAC1, at chromosome 10q23.3 that is mutated in multiple advanced cancers. Nat. Genet. 1997, 15, 356-362. [CrossRef]

7. Knobbe, C.B.; Reifenberger, G. Genetic alterations and aberrant expression of genes related to the phosphatidyl-inositol-3'-kinase/protein kinase B (Akt) signal transduction pathway in glioblastomas. Brain Pathol. 2003, 13, 507-518. [CrossRef]

8. Shayesteh, L.; Lu, Y.; Kuo, W.L.; Baldocchi, R.; Godfrey, T.; Collins, C.; Pinkel, D.; Powell, B.; Mills, G.B.; Gray, J.W. PIK3CA is implicated as an oncogene in ovarian cancer. Nat. Genet. 1999, 21, 99-102. [CrossRef]

9. Philp, A.J.; Campbell, I.G.; Leet, C.; Vincan, E.; Rockman, S.P.; Whitehead, R.H.; Thomas, R.J.; Phillips, W.A. The phosphatidylinositol 3'-kinase p85alpha gene is an oncogene in human ovarian and colon tumors. Cancer Res. 2001, 61, 7426-7429.

10. Millis, S.Z.; Jardim, D.L.; Albacker, L.; Ross, J.S.; Miller, V.A.; Ali, S.M.; Kurzrock, R. Phosphatidylinositol 3-kinase pathway genomic alterations in 60,991 diverse solid tumors informs targeted therapy opportunities. Cancer 2019, 125, 1185-1199. [CrossRef] 
11. Elwy, F.; Helwa, R.; El Leithy, A.A.; Shehab El din, Z.; Assem, M.M.; Hassan, N.H. PIK3CA mutations in HER2-positive Breast Cancer Patients; Frequency and Clinicopathological Perspective in Egyptian Patients. Asian Pac. J. Cancer Prev. 2017, 18, 57-64. [CrossRef] [PubMed]

12. Samuels, Y.; Wang, Z.; Bardelli, A.; Silliman, N.; Ptak, J.; Szabo, S.; Yan, H.; Gazdar, A.; Powell, S.M.; Riggins, G.J.; et al. High frequency of mutations of the PIK3CA gene in human cancers. Science 2004, 304, 554. [CrossRef] [PubMed]

13. Bachman, K.E.; Argani, P.; Samuels, Y.; Silliman, N.; Ptak, J.; Szabo, S.; Konishi, H.; Karakas, B.; Blair, B.G.; Lin, C.; et al. The PIK3CA gene is mutated with high frequency in human breast cancers. Cancer Biol. Ther. 2004, 3, 772-775. [CrossRef]

14. Saal, L.H.; Holm, K.; Maurer, M.; Memeo, L.; Su, T.; Wang, X.; Yu, J.S.; Malmstrom, P.O.; Mansukhani, M.; Enoksson, J.; et al. PIK3CA mutations correlate with hormone receptors, node metastasis, and ERBB2, and are mutually exclusive with PTEN loss in human breast carcinoma. Cancer Res. 2005, 65, 2554-2559. [CrossRef] [PubMed]

15. Jhawer, M.; Goel, S.; Wilson, A.J.; Montagna, C.; Ling, Y.H.; Byun, D.S.; Nasser, S.; Arango, D.; Shin, J.; Klampfer, L.; et al. PIK3CA mutation/PTEN expression status predicts response of colon cancer cells to the epidermal growth factor receptor inhibitor cetuximab. Cancer Res. 2008, 68, 1953-1961. [CrossRef] [PubMed]

16. Sartore-Bianchi, A.; Martini, M.; Molinari, F.; Veronese, S.; Nichelatti, M.; Artale, S.; Di Nicolantonio, F.; Saletti, P.; De Dosso, S.; Mazzucchelli, L.; et al. PIK3CA mutations in colorectal cancer are associated with clinical resistance to EGFR-targeted monoclonal antibodies. Cancer Res. 2009, 69, 1851-1857. [CrossRef] [PubMed]

17. Ogino, S.; Liao, X.; Imamura, Y.; Yamauchi, M.; McCleary, N.J.; Ng, K.; Niedzwiecki, D.; Saltz, L.B.; Mayer, R.J.; Whittom, R.; et al. Predictive and prognostic analysis of PIK3CA mutation in stage III colon cancer intergroup trial. J. Natl. Cancer Inst. 2013, 105, 1789-1798. [CrossRef]

18. Reggiani Bonetti, L.; Barresi, V.; Maiorana, A.; Manfredini, S.; Caprera, C.; Bettelli, S. Clinical Impact and Prognostic Role of KRAS/BRAF/PIK3CA Mutations in Stage I Colorectal Cancer. Dis. Markers 2018, 2018, 2959801. [CrossRef]

19. Gong, J.; Cho, M.; Sy, M.; Salgia, R.; Fakih, M. Molecular profiling of metastatic colorectal tumors using next-generation sequencing: A single-institution experience. Oncotarget 2017, 8, 42198-42213. [CrossRef]

20. Benvenuti, S.; Frattini, M.; Arena, S.; Zanon, C.; Cappelletti, V.; Coradini, D.; Daidone, M.G.; Pilotti, S.; Pierotti, M.A.; Bardelli, A. PIK3CA cancer mutations display gender and tissue specificity patterns. Hum. Mutat. 2008, 29, 284-288. [CrossRef]

21. Fang, W.L.; Huang, K.H.; Lan, Y.T.; Lin, C.H.; Chang, S.C.; Chen, M.H.; Chao, Y.; Lin, W.C.; Lo, S.S.; Li, A.F.; et al. Mutations in PI3K/AKT pathway genes and amplifications of PIK3CA are associated with patterns of recurrence in gastric cancers. Oncotarget 2016, 7, 6201-6220. [CrossRef] [PubMed]

22. Phipps, A.I.; Ahnen, D.J.; Cheng, I.; Newcomb, P.A.; Win, A.K.; Burnett, T. PIK3CA Somatic Mutation Status in Relation to Patient and Tumor Factors in Racial/Ethnic Minorities with Colorectal Cancer. Cancer Epidemiol. Biomarkers Prev. 2015, 24, 1046-1051. [CrossRef] [PubMed]

23. Ding, W.J.; Zeng, T.; Wang, L.J.; Lei, H.B.; Ge, W.; Wang, Z. Genes with mutation significance were highly associated with the clinical pattern of patients with breast cancer. Oncotarget 2017, 8, 98094-98102. [CrossRef] [PubMed]

24. Stemke-Hale, K.; Gonzalez-Angulo, A.M.; Lluch, A.; Neve, R.M.; Kuo, W.L.; Davies, M.; Carey, M.; Hu, Z.; Guan, Y.; Sahin, A.; et al. An integrative genomic and proteomic analysis of PIK3CA, PTEN, and AKT mutations in breast cancer. Cancer Res. 2008, 68, 6084-6091. [CrossRef] [PubMed]

25. Hu, Z.Y.; Xie, N.; Tian, C.; Yang, X.; Liu, L.; Li, J.; Xiao, H.; Wu, H.; Lu, J.; Gao, J.; et al. Identifying Circulating Tumor DNA Mutation Profiles in Metastatic Breast Cancer Patients with Multiline Resistance. EBioMedicine 2018, 32, 111-118. [CrossRef]

26. Wu, H.; Wang, W.; Du, J.; Li, H.; Wang, H.; Huang, L.; Xiang, H.; Xie, J.; Liu, X.; Li, H.; et al. The distinct clinicopathological and prognostic implications of PIK3CA mutations in breast cancer patients from Central China. Cancer Manag. Res. 2019, 11, 1473-1492. [CrossRef]

27. Chen, X.; Guo, Y.; Ouyang, T.; Li, J.; Wang, T.; Fan, Z.; Fan, T.; Lin, B.; Xu, Y.; Xie, Y. Co-mutation of TP53 and PIK3CA in residual disease after neoadjuvant chemotherapy is associated with poor survival in breast cancer. J. Cancer Res. Clin. Oncol. 2019, 145, 1235-1242. [CrossRef] 
28. Tsai, Y.J.; Huang, S.C.; Lin, H.H.; Lin, C.C.; Lan, Y.T.; Wang, H.S.; Yang, S.H.; Jiang, J.K.; Chen, W.S.; Lin, T.C.; et al. Differences in gene mutations according to gender among patients with colorectal cancer. World J. Surg. Oncol. 2018, 16, 128. [CrossRef]

29. Christensen, T.D.; Palshof, J.A.; Larsen, F.O.; Poulsen, T.S.; Hogdall, E.; Pfeiffer, P.; Jensen, B.V.; Yilmaz, M.K.; Nielsen, D. Associations between primary tumor RAS, BRAF and PIK3CA mutation status and metastatic site in patients with chemo-resistant metastatic colorectal cancer. Acta Oncol. 2018, 57, 1057-1062. [CrossRef]

30. Barbareschi, M.; Buttitta, F.; Felicioni, L.; Cotrupi, S.; Barassi, F.; Del Grammastro, M.; Ferro, A.; Dalla Palma, P.; Galligioni, E.; Marchetti, A. Different prognostic roles of mutations in the helical and kinase domains of the PIK3CA gene in breast carcinomas. Clin. Cancer Res. 2007, 13, 6064-6069. [CrossRef]

31. Deng, L.; Zhu, X.; Sun, Y.; Wang, J.; Zhong, X.; Li, J.; Hu, M.; Zheng, H. Prevalence and Prognostic Role of PIK3CA/AKT1 Mutations in Chinese Breast Cancer Patients. Cancer Res. Treat. 2019, 51, 128-140. [CrossRef] [PubMed]

32. Perez-Tenorio, G.; Alkhori, L.; Olsson, B.; Waltersson, M.A.; Nordenskjold, B.; Rutqvist, L.E.; Skoog, L.; Stal, O. PIK3CA mutations and PTEN loss correlate with similar prognostic factors and are not mutually exclusive in breast cancer. Clin. Cancer Res. 2007, 13, 3577-3584. [CrossRef] [PubMed]

33. Cizkova, M.; Susini, A.; Vacher, S.; Cizeron-Clairac, G.; Andrieu, C.; Driouch, K.; Fourme, E.; Lidereau, R.; Bieche, I. PIK3CA mutation impact on survival in breast cancer patients and in ERalpha, PR and ERBB2-based subgroups. Breast Cancer Res. 2012, 14, R28. [CrossRef] [PubMed]

34. Buttitta, F.; Felicioni, L.; Barassi, F.; Martella, C.; Paolizzi, D.; Fresu, G.; Salvatore, S.; Cuccurullo, F.; Mezzetti, A.; Campani, D.; et al. PIK3CA mutation and histological type in breast carcinoma: High frequency of mutations in lobular carcinoma. J. Pathol. 2006, 208, 350-355. [CrossRef]

35. Mangone, F.R.; Bobrovnitchaia, I.G.; Salaorni, S.; Manuli, E.; Nagai, M.A. PIK3CA exon 20 mutations are associated with poor prognosis in breast cancer patients. Clinics 2012, 67, 1285-1290. [CrossRef]

36. Deng, L.; Chen, J.; Zhong, X.R.; Luo, T.; Wang, Y.P.; Huang, H.F.; Yin, L.J.; Qiu, Y.; Bu, H.; Lv, Q.; et al. Correlation between activation of PI3K/AKT/mTOR pathway and prognosis of breast cancer in Chinese women. PLoS ONE 2015, 10, e0120511. [CrossRef]

37. Seo, Y.; Park, Y.H.; Ahn, J.S.; Im, Y.H.; Nam, S.J.; Cho, S.Y.; Cho, E.Y. PIK3CA Mutations and Neoadjuvant Therapy Outcome in Patients with Human Epidermal Growth Factor Receptor 2-Positive Breast Cancer: A Sequential Analysis. J. Breast Cancer 2018, 21, 382-390. [CrossRef]

38. Berns, K.; Horlings, H.M.; Hennessy, B.T.; Madiredjo, M.; Hijmans, E.M.; Beelen, K.; Linn, S.C.; Gonzalez-Angulo, A.M.; Stemke-Hale, K.; Hauptmann, M.; et al. A functional genetic approach identifies the PI3K pathway as a major determinant of trastuzumab resistance in breast cancer. Cancer Cell 2007, 12, 395-402. [CrossRef]

39. Maruyama, N.; Miyoshi, Y.; Taguchi, T.; Tamaki, Y.; Monden, M.; Noguchi, S. Clinicopathologic analysis of breast cancers with PIK3CA mutations in Japanese women. Clin. Cancer Res. 2007, 13, 408-414. [CrossRef]

40. Eichhorn, P.J.; Gili, M.; Scaltriti, M.; Serra, V.; Guzman, M.; Nijkamp, W.; Beijersbergen, R.L.; Valero, V.; Seoane, J.; Bernards, R.; et al. Phosphatidylinositol 3-kinase hyperactivation results in lapatinib resistance that is reversed by the mTOR/phosphatidylinositol 3-kinase inhibitor NVP-BEZ235. Cancer Res. 2008, 68, 9221-9230. [CrossRef]

41. Yang, L.; Ye, F.; Bao, L.; Zhou, X.; Wang, Z.; Hu, P.; Ouyang, N.; Li, X.; Shi, Y.; Chen, G.; et al. Somatic alterations of TP53, ERBB2, PIK3CA and CCND1 are associated with chemosensitivity for breast cancers. Cancer Sci. 2019, 110, 1389-1400. [CrossRef] [PubMed]

42. Miller, T.W.; Hennessy, B.T.; Gonzalez-Angulo, A.M.; Fox, E.M.; Mills, G.B.; Chen, H.; Higham, C.; Garcia-Echeverria, C.; Shyr, Y.; Arteaga, C.L. Hyperactivation of phosphatidylinositol-3 kinase promotes escape from hormone dependence in estrogen receptor-positive human breast cancer. J. Clin. Investig. 2010, 120, 2406-2413. [CrossRef] [PubMed]

43. Liedtke, C.; Cardone, L.; Tordai, A.; Yan, K.; Gomez, H.L.; Figureoa, L.J.; Hubbard, R.E.; Valero, V.; Souchon, E.A.; Symmans, W.F.; et al. PIK3CA-activating mutations and chemotherapy sensitivity in stage II-III breast cancer. Breast Cancer Res. 2008, 10, R27. [CrossRef]

44. Brown, K.K.; Toker, A. The phosphoinositide 3-kinase pathway and therapy resistance in cancer. F1000Prime Rep. 2015, 7, 13. [CrossRef] 
45. Baselga, J.; Cortes, J.; Kim, S.B.; Im, S.A.; Hegg, R.; Im, Y.H.; Roman, L.; Pedrini, J.L.; Pienkowski, T.; Knott, A.; et al. Pertuzumab plus trastuzumab plus docetaxel for metastatic breast cancer. N. Engl. J. Med. 2012, 366, 109-119. [CrossRef]

46. Zhou, D.; Ouyang, Q.; Liu, L.; Liu, J.; Tang, Y.; Xiao, M.; Wang, Y.; He, Q.; Hu, Z.Y. Chemotherapy Modulates Endocrine Therapy-Related Resistance Mutations in Metastatic Breast Cancer. Transl. Oncol. 2019, 12, 764-774. [CrossRef]

47. Salem, M.E.; Weinberg, B.A.; Xiu, J.; El-Deiry, W.S.; Hwang, J.J.; Gatalica, Z.; Philip, P.A.; Shields, A.F.; Lenz, H.J.; Marshall, J.L. Comparative molecular analyses of left-sided colon, right-sided colon, and rectal cancers. Oncotarget 2017, 8, 86356-86368. [CrossRef]

48. Li, X.; Yang, T.; Li, C.S.; Song, Y.; Lou, H.; Guan, D.; Jin, L. Surface Enhanced Raman Spectroscopy (SERS) for the Multiplex Detection of Braf, Kras, and Pik3ca Mutations in Plasma of Colorectal Cancer Patients. Theranostics 2018, 8, 1678-1689. [CrossRef]

49. Mikami, M.; Nosho, K.; Yamamoto, H.; Takahashi, T.; Maehata, T.; Taniguchi, H.; Adachi, Y.; Imamura, A.; Fujita, M.; Hosokawa, M.; et al. Mutational analysis of beta-catenin and the RAS-RAF signalling pathway in early flat-type colorectal tumours. Eur. J. Cancer 2006, 42, 3065-3072. [CrossRef]

50. Miyaki, M.; Iijima, T.; Yamaguchi, T.; Takahashi, K.; Matsumoto, H.; Yasutome, M.; Funata, N.; Mori, T. Mutations of the PIK3CA gene in hereditary colorectal cancers. Int. J. Cancer 2007, 121, 1627-1630. [CrossRef]

51. Reggiani Bonetti, L.; Barresi, V.; Bettelli, S.; Caprera, C.; Manfredini, S.; Maiorana, A. Analysis of KRAS, NRAS, PIK3CA, and BRAF mutational profile in poorly differentiated clusters of KRAS-mutated colon cancer. Hum. Pathol. 2017, 62, 91-98. [CrossRef]

52. Barault, L.; Veyrie, N.; Jooste, V.; Lecorre, D.; Chapusot, C.; Ferraz, J.M.; Lievre, A.; Cortet, M.; Bouvier, A.M.; Rat, P.; et al. Mutations in the RAS-MAPK, PI(3)K (phosphatidylinositol-3-OH kinase) signaling network correlate with poor survival in a population-based series of colon cancers. Int. J. Cancer 2008, 122, 2255-2259. [CrossRef]

53. Ogino, S.; Nosho, K.; Kirkner, G.J.; Shima, K.; Irahara, N.; Kure, S.; Chan, A.T.; Engelman, J.A.; Kraft, P.; Cantley, L.C.; et al. PIK3CA mutation is associated with poor prognosis among patients with curatively resected colon cancer. J. Clin. Oncol. 2009, 27, 1477-1484. [CrossRef]

54. Foltran, L.; De Maglio, G.; Pella, N.; Ermacora, P.; Aprile, G.; Masiero, E.; Giovannoni, M.; Iaiza, E.; Cardellino, G.G.; Lutrino, S.E.; et al. Prognostic role of KRAS, NRAS, BRAF and PIK3CA mutations in advanced colorectal cancer. Future Oncol. 2015, 11, 629-640. [CrossRef]

55. Manceau, G.; Marisa, L.; Boige, V.; Duval, A.; Gaub, M.P.; Milano, G.; Selves, J.; Olschwang, S.; Jooste, V.; le Legrain, M.; et al. PIK3CA mutations predict recurrence in localized microsatellite stable colon cancer. Cancer Med. 2015, 4, 371-382. [CrossRef]

56. Michel, P.; Boige, V.; Andre, T.; Aparicio, T.; Bachet, J.B.; Dahan, L.; Guimbaud, R.; Lepage, C.; Manfredi, S.; Tougeron, D.; et al. Aspirin versus placebo in stage III or high-risk stage II colon cancer with PIK3CA mutation: A French randomised double-blind phase III trial (PRODIGE 50-ASPIK). Dig. Liver Dis. 2018, 50, 305-307. [CrossRef]

57. Li, P.; Wu, H.; Zhang, H.; Shi, Y.; Xu, J.; Ye, Y.; Xia, D.; Yang, J.; Cai, J.; Wu, Y. Aspirin use after diagnosis but not prediagnosis improves established colorectal cancer survival: A meta-analysis. Gut 2015, 64, 1419-1425. [CrossRef]

58. Massion, P.P.; Taflan, P.M.; Shyr, Y.; Rahman, S.M.; Yildiz, P.; Shakthour, B.; Edgerton, M.E.; Ninan, M.; Andersen, J.J.; Gonzalez, A.L. Early involvement of the phosphatidylinositol 3-kinase/Akt pathway in lung cancer progression. Am. J. Respir. Crit. Care Med. 2004, 170, 1088-1094. [CrossRef]

59. Youssef, O.; Knuuttila, A.; Piirila, P.; Bohling, T.; Sarhadi, V.; Knuutila, S. Hotspot Mutations Detectable by Next-generation Sequencing in Exhaled Breath Condensates from Patients with Lung Cancer. Anticancer Res. 2018, 38, 5627-5634. [CrossRef]

60. Kawano, O.; Sasaki, H.; Endo, K.; Suzuki, E.; Haneda, H.; Yukiue, H.; Kobayashi, Y.; Yano, M.; Fujii, Y. PIK3CA mutation status in Japanese lung cancer patients. Lung Cancer 2006, 54, 209-215. [CrossRef]

61. Okudela, K.; Suzuki, M.; Kageyama, S.; Bunai, T.; Nagura, K.; Igarashi, H.; Takamochi, K.; Suzuki, K.; Yamada, T.; Niwa, H.; et al. PIK3CA mutation and amplification in human lung cancer. Pathol. Int. 2007, 57, 664-671. [CrossRef] 
62. Yamamoto, H.; Shigematsu, H.; Nomura, M.; Lockwood, W.W.; Sato, M.; Okumura, N.; Soh, J.; Suzuki, M.; Wistuba, I.; Fong, K.M.; et al. PIK3CA mutations and copy number gains in human lung cancers. Cancer Res. 2008, 68, 6913-6921. [CrossRef]

63. Shi, R.; Li, M.; Raghavan, V.; Tam, S.; Cabanero, M.; Pham, N.A.; Shepherd, F.A.; Moghal, N.; Tsao, M.S. Targeting the CDK4/6-Rb Pathway Enhances Response to PI3K Inhibition in PIK3CA-Mutant Lung Squamous Cell Carcinoma. Clin. Cancer Res. 2018, 24, 5990-6000. [CrossRef]

64. Kawano, O.; Sasaki, H.; Okuda, K.; Yukiue, H.; Yokoyama, T.; Yano, M.; Fujii, Y. PIK3CA gene amplification in Japanese non-small cell lung cancer. Lung Cancer 2007, 58, 159-160. [CrossRef]

65. Wu, S.G.; Liu, Y.N.; Yu, C.J.; Yang, J.C.; Shih, J.Y. Driver mutations of young lung adenocarcinoma patients with malignant pleural effusion. Genes Chromosomes Cancer 2018, 57, 513-521. [CrossRef]

66. Jing, C.; Mao, X.; Wang, Z.; Sun, K.; Ma, R.; Wu, J.; Cao, H. Nextgeneration sequencingbased detection of EGFR, KRAS, BRAF, NRAS, PIK3CA, Her2 and TP53 mutations in patients with nonsmall cell lung cancer. Mol. Med. Rep. 2018, 18, 2191-2197. [CrossRef]

67. Li, W.; Qiu, T.; Ling, Y.; Gao, S.; Ying, J. Subjecting appropriate lung adenocarcinoma samples to next-generation sequencing-based molecular testing: challenges and possible solutions. Mol. Oncol. 2018, 12, 677-689. [CrossRef]

68. Lockney, N.A.; Yang, T.J.; Barron, D.; Gelb, E.; Gelblum, D.Y.; Yorke, E.; Shi, W.; Zhang, Z.; Rimner, A.; $\mathrm{Wu}$, A.J. PIK3CA mutation is associated with increased local failure in lung stereotactic body radiation therapy (SBRT). Clin. Transl. Radiat. Oncol. 2017, 7, 91-93. [CrossRef]

69. Zhao, J.; Han, Y.; Li, J.; Chai, R.; Bai, C. Prognostic value of KRAS/TP53/PIK3CA in non-small cell lung cancer. Oncol. Lett. 2019, 17, 3233-3240. [CrossRef]

70. Kunstman, J.W.; Juhlin, C.C.; Goh, G.; Brown, T.C.; Stenman, A.; Healy, J.M.; Rubinstein, J.C.; Choi, M.; Kiss, N.; Nelson-Williams, C.; et al. Characterization of the mutational landscape of anaplastic thyroid cancer via whole-exome sequencing. Hum. Mol. Genet. 2015, 24, 2318-2329. [CrossRef]

71. Xing, M. Genetic alterations in the phosphatidylinositol-3 kinase/Akt pathway in thyroid cancer. Thyroid 2010, 20, 697-706. [CrossRef]

72. Jeon, M.J.; Song, D.E.; Jung, C.K.; Kim, W.G.; Kwon, H.; Lee, Y.M.; Sung, T.Y.; Yoon, J.H.; Chung, K.W.; Hong, S.J.; et al. Impact of Reclassification on Thyroid Nodules with Architectural Atypia: From Non-Invasive Encapsulated Follicular Variant Papillary Thyroid Carcinomas to Non-Invasive Follicular Thyroid Neoplasm with Papillary-Like Nuclear Features. PLoS ONE 2016, 11, e0167756. [CrossRef]

73. Garcia-Rostan, G.; Costa, A.M.; Pereira-Castro, I.; Salvatore, G.; Hernandez, R.; Hermsem, M.J.; Herrero, A.; Fusco, A.; Cameselle-Teijeiro, J.; Santoro, M. Mutation of the PIK3CA gene in anaplastic thyroid cancer. Cancer Res. 2005, 65, 10199-10207. [CrossRef]

74. Wu, M.; Szporn, A.H.; Zhang, D.; Wasserman, P.; Gan, L.; Miller, L.; Burstein, D.E. Cytology applications of p63 and TTF-1 immunostaining in differential diagnosis of lung cancers. Diagn. Cytopathol. 2005, 33, $223-227$. [CrossRef]

75. Qiu, W.; Tong, G.X.; Manolidis, S.; Close, L.G.; Assaad, A.M.; Su, G.H. Novel mutant-enriched sequencing identified high frequency of PIK3CA mutations in pharyngeal cancer. Int. J. Cancer 2008, 122, 1189-1194. [CrossRef]

76. Abubaker, J.; Jehan, Z.; Bavi, P.; Sultana, M.; Al-Harbi, S.; Ibrahim, M.; Al-Nuaim, A.; Ahmed, M.; Amin, T.; Al-Fehaily, M.; et al. Clinicopathological analysis of papillary thyroid cancer with PIK3CA alterations in a Middle Eastern population. J. Clin. Endocrinol. Metab. 2008, 93, 611-618. [CrossRef]

77. Santarpia, L.; El-Naggar, A.K.; Cote, G.J.; Myers, J.N.; Sherman, S.I. Phosphatidylinositol 3-kinase/akt and ras/raf-mitogen-activated protein kinase pathway mutations in anaplastic thyroid cancer. J. Clin. Endocrinol. Metab. 2008, 93, 278-284. [CrossRef]

78. Schechter, R.B.; Nagilla, M.; Joseph, L.; Reddy, P.; Khattri, A.; Watson, S.; Locati, L.D.; Licitra, L.; Greco, A.; Pelosi, G.; et al. Genetic profiling of advanced radioactive iodine-resistant differentiated thyroid cancer and correlation with axitinib efficacy. Cancer Lett. 2015, 359, 269-274. [CrossRef]

79. Alzahrani, A.S.; Murugan, A.K.; Qasem, E.; Alswailem, M.; Al-Hindi, H.; Shi, Y. Single Point Mutations in Pediatric Differentiated Thyroid Cancer. Thyroid 2017, 27, 189-196. [CrossRef]

80. Charles, R.P.; Silva, J.; Iezza, G.; Phillips, W.A.; McMahon, M. Activating BRAF and PIK3CA mutations cooperate to promote anaplastic thyroid carcinogenesis. Mol. Cancer Res. 2014, 12, 979-986. [CrossRef] 
81. Xing, J.C.; Tufano, R.P.; Murugan, A.K.; Liu, D.; Wand, G.; Ladenson, P.W.; Xing, M.; Trink, B. Single nucleotide polymorphism rs17849071 G/T in the PIK3CA gene is inversely associated with follicular thyroid cancer and PIK3CA amplification. PLoS ONE 2012, 7, e49192. [CrossRef]

82. Lee, M.Y.; Ku, B.M.; Kim, H.S.; Lee, J.Y.; Lim, S.H.; Sun, J.M.; Lee, S.H.; Park, K.; Oh, Y.L.; Hong, M.; et al. Genetic Alterations and Their Clinical Implications in High-Recurrence Risk Papillary Thyroid Cancer. Cancer Res. Treat. 2017, 49, 906-914. [CrossRef]

83. Morandi, L.; Righi, A.; Maletta, F.; Rucci, P.; Pagni, F.; Gallo, M.; Rossi, S.; Caporali, L.; Sapino, A.; Lloyd, R.V.; et al. Somatic mutation profiling of hobnail variant of papillary thyroid carcinoma. Endocr. Relat. Cancer 2017, 24, 107-117. [CrossRef]

84. Bandoh, N.; Akahane, T.; Goto, T.; Kono, M.; Ichikawa, H.; Sawada, T.; Yamaguchi, T.; Nakano, H.; Kawase, Y.; Kato, Y.; et al. Targeted next-generation sequencing of cancer-related genes in thyroid carcinoma: A single institution's experience. Oncol. Lett. 2018, 16, 7278-7286. [CrossRef]

85. Kozaki, K.; Imoto, I.; Pimkhaokham, A.; Hasegawa, S.; Tsuda, H.; Omura, K.; Inazawa, J. PIK3CA mutation is an oncogenic aberration at advanced stages of oral squamous cell carcinoma. Cancer Sci. 2006, 97, 1351-1358. [CrossRef]

86. Murugan, A.K.; Hong, N.T.; Fukui, Y.; Munirajan, A.K.; Tsuchida, N. Oncogenic mutations of the PIK3CA gene in head and neck squamous cell carcinomas. Int. J. Oncol. 2008, 32, 101-111. [CrossRef]

87. Ludwig, M.L.; Kulkarni, A.; Birkeland, A.C.; Michmerhuizen, N.L.; Foltin, S.K.; Mann, J.E.; Hoesli, R.C.; Devenport, S.N.; Jewell, B.M.; Shuman, A.G.; et al. The genomic landscape of UM-SCC oral cavity squamous cell carcinoma cell lines. Oral Oncol. 2018, 87, 144-151. [CrossRef]

88. Schmidt, H.; Kulasinghe, A.; Allcock, R.J.N.; Tan, L.Y.; Mokany, E.; Kenny, L.; Punyadeera, C. A Pilot Study to Non-Invasively Track PIK3CA Mutation in Head and Neck Cancer. Diagnostics 2018, 8, 79. [CrossRef]

89. Saintigny, P.; Mitani, Y.; Pytynia, K.B.; Ferrarotto, R.; Roberts, D.B.; Weber, R.S.; Kies, M.S.; Maity, S.N.; Lin, S.H.; El-Naggar, A.K. Frequent PTEN loss and differential HER2/PI3K signaling pathway alterations in salivary duct carcinoma: Implications for targeted therapy. Cancer 2018, 124, 3693-3705. [CrossRef]

90. Nakagaki, T.; Tamura, M.; Kobashi, K.; Omori, A.; Koyama, R.; Idogawa, M.; Ogi, K.; Hiratsuka, H.; Tokino, T.; Sasaki, Y. Targeted next-generation sequencing of 50 cancer-related genes in Japanese patients with oral squamous cell carcinoma. Tumour Biol. 2018, 40, 1010428318800180. [CrossRef]

91. Gillison, M.L.; Akagi, K.; Xiao, W.; Jiang, B.; Pickard, R.K.L.; Li, J.; Swanson, B.J.; Agrawal, A.D.; Zucker, M.; Stache-Crain, B.; et al. Human papillomavirus and the landscape of secondary genetic alterations in oral cancers. Genome Res. 2019, 29, 1-17. [CrossRef] [PubMed]

92. Ruicci, K.M.; Meens, J.; Sun, R.X.; Rizzo, G.; Pinto, N.; Yoo, J.; Fung, K.; MacNeil, D.; Mymryk, J.S.; Barrett, J.W.; et al. A controlled trial of HNSCC patient-derived xenografts reveals broad efficacy of PI3Kalpha inhibition in controlling tumor growth. Int. J. Cancer 2019, 145, 2100-2106. [CrossRef] [PubMed]

93. Kang, H.; Pettinga, D.; Schubert, A.D.; Ladenson, P.W.; Ball, D.W.; Chung, J.H.; Schrock, A.B.; Madison, R.; Frampton, G.M.; Stephens, P.J.; et al. Genomic Profiling of Parathyroid Carcinoma Reveals Genomic Alterations Suggesting Benefit from Therapy. Oncologist 2019, 24, 791-797. [CrossRef] [PubMed]

94. Chou, C.C.; Chou, M.J.; Tzen, C.Y. PIK3CA mutation occurs in nasopharyngeal carcinoma but does not significantly influence the disease-specific survival. Med. Oncol. 2009, 26, 322-326. [CrossRef]

95. Hedberg, M.L.; Peyser, N.D.; Bauman, J.E.; Gooding, W.E.; Li, H.; Bhola, N.E.; Zhu, T.R.; Zeng, Y.; Brand, T.M.; Kim, M.O.; et al. Use of nonsteroidal anti-inflammatory drugs predicts improved patient survival for PIK3CA-altered head and neck cancer. J. Exp. Med. 2019, 216, 419-427. [CrossRef]

96. Hanna, G.J.; Kacew, A.; Chau, N.G.; Shivdasani, P.; Lorch, J.H.; Uppaluri, R.; Haddad, R.I.; MacConaill, L.E. Improved outcomes in PI3K-pathway-altered metastatic HPV oropharyngeal cancer. JCI Insight 2018, 3. [CrossRef]

97. Resteghini, C.; Perrone, F.; Miceli, R.; Bergamini, C.; Alfieri, S.; Orlandi, E.; Guzzo, M.; Granata, R.; Galbiati, D.; Cavalieri, S.; et al. Prognostic role of PIK3CA and TP53 in human papillomavirus-negative oropharyngeal cancers. Tumori 2018, 104, 213-220. [CrossRef]

98. Dunn, L.A.; Fury, M.G.; Xiao, H.; Baxi, S.S.; Sherman, E.J.; Korte, S.; Pfister, C.; Haque, S.; Katabi, N.; Ho, A.L.; et al. A phase II study of temsirolimus added to low-dose weekly carboplatin and paclitaxel for patients with recurrent and/or metastatic (R/M) head and neck squamous cell carcinoma (HNSCC). Ann. Oncol. 2017, 28, 2533-2538. [CrossRef] 
99. Munari, F.F.; Cruvinel-Carloni, A.; Lacerda, C.F.; de Oliveira, A.T.T.; Scapulatempo-Neto, C.; da Silva, S.R.M.; Crema, E.; Adad, S.J.; Rodrigues, M.A.M.; Henry, M.; et al. PIK3CA mutations are frequent in esophageal squamous cell carcinoma associated with chagasic megaesophagus and are associated with a worse patient outcome. Infect. Agent Cancer 2018, 13, 43. [CrossRef]

100. Akagi, I.; Miyashita, M.; Makino, H.; Nomura, T.; Hagiwara, N.; Takahashi, K.; Cho, K.; Mishima, T.; Ishibashi, O.; Ushijima, T.; et al. Overexpression of PIK3CA is associated with lymph node metastasis in esophageal squamous cell carcinoma. Int. J. Oncol. 2009, 34, 767-775. [CrossRef]

101. Kobayashi, S.; Yamaguchi, T.; Maekawa, S.; Takano, S.; Kuno, T.; Tanaka, K.; Tsukui, Y.; Iwamoto, F.; Yoshida, T.; Asakawa, Y.; et al. Target sequencing of cancer-related genes in early esophageal squamous neoplasia resected by endoscopic resection in Japanese patients. Oncotarget 2018, 9, 36793-36803. [CrossRef]

102. Lu, H.; Jiang, T.; Ren, K.; Li, Z.L.; Ren, J.; Wu, G.; Han, X. RUNX2 Plays An Oncogenic Role in Esophageal Carcinoma by Activating the PI3K/AKT and ERK Signaling Pathways. Cell Physiol. Biochem. 2018, 49, 217-225. [CrossRef]

103. Ge, X.Q.; Yang, Y.Z.; Li, S.S.; Hou, L.; Ren, J.L.; Yang, K.P.; Fa, X.E. No significant association between PIK3CA mutation and survival of esophageal squamous cell carcinoma: A meta-analysis. J. Huazhong Univ. Sci. Technol. Med. Sci. 2017, 37, 462-468. [CrossRef]

104. Liu, S.Y.; Chen, W.; Chughtai, E.A.; Qiao, Z.; Jiang, J.T.; Li, S.M.; Zhang, W.; Zhang, J. PIK3CA gene mutations in Northwest Chinese esophageal squamous cell carcinoma. World J. Gastroenterol. 2017, 23, 2585-2591. [CrossRef]

105. Brugarolas, J. Molecular genetics of clear-cell renal cell carcinoma. J. Clin. Oncol. 2014, 32, 1968-1976. [CrossRef]

106. Yokota, T.; Serizawa, M.; Hosokawa, A.; Kusafuka, K.; Mori, K.; Sugiyama, T.; Tsubosa, Y.; Koh, Y. PIK3CA mutation is a favorable prognostic factor in esophageal cancer: molecular profile by next-generation sequencing using surgically resected formalin-fixed, paraffin-embedded tissue. BMC Cancer 2018, 18, 826. [CrossRef]

107. Liu, Q.; Cornejo, K.M.; Cheng, L.; Hutchinson, L.; Wang, M.; Zhang, S.; Tomaszewicz, K.; Cosar, E.F.; Woda, B.A.; Jiang, Z. Next-Generation Sequencing to Detect Deletion of RB1 and ERBB4 Genes in Chromophobe Renal Cell Carcinoma: A Potential Role in Distinguishing Chromophobe Renal Cell Carcinoma from Renal Oncocytoma. Am. J. Pathol. 2018, 188, 846-852. [CrossRef]

108. Gasinska, A.; Jaszczynski, J.; Adamczyk, A.; Janecka-Widla, A.; Wilk, W.; Cichocka, A.; Stelmach, A. Biomarkers of epithelial-mesenchymal transition in localized, surgically treated clear-cell renal cell carcinoma. Folia Histochem. Cytobiol. 2018, 56, 195-206. [CrossRef]

109. Gripp, K.W.; Baker, L.; Kandula, V.; Conard, K.; Scavina, M.; Napoli, J.A.; Griffin, G.C.; Thacker, M.; Knox, R.G.; Clark, G.R.; et al. Nephroblastomatosis or Wilms tumor in a fourth patient with a somatic PIK3CA mutation. Am. J. Med. Genet. A 2016, 170, 2559-2569. [CrossRef]

110. Isharwal, S.; Hu, W.; Sarungbam, J.; Chen, Y.B.; Gopalan, A.; Fine, S.W.; Tickoo, S.K.; Sirintrapun, S.J.; Jadallah, S.; Loo, F.L.; et al. Genomic landscape of inverted urothelial papilloma and urothelial papilloma of the bladder. J. Pathol. 2019, 248, 260-265. [CrossRef]

111. Li, C.; Bonazzoli, E.; Bellone, S.; Choi, J.; Dong, W.; Menderes, G.; Altwerger, G.; Han, C.; Manzano, A.; Bianchi, A.; et al. Mutational landscape of primary, metastatic, and recurrent ovarian cancer reveals c-MYC gains as potential target for BET inhibitors. Proc. Natl. Acad. Sci. USA 2019, 116, 619-624. [CrossRef]

112. Van Nieuwenhuysen, E.; Busschaert, P.; Neven, P.; Han, S.N.; Moerman, P.; Liontos, M.; Papaspirou, M.; Kupryjanczyk, J.; Hogdall, C.; Hogdall, E.; et al. The genetic landscape of 87 ovarian germ cell tumors. Gynecol. Oncol. 2018, 151, 61-68. [CrossRef]

113. Malentacchi, F.; Turrini, I.; Sorbi, F.; Projetto, E.; Castiglione, F.; Fambrini, M.; Petraglia, F.; Pillozzi, S.; Noci, I. Pilot investigation of the mutation profile of PIK3CA/PTEN genes (PI3K pathway) in grade 3 endometrial cancer. Oncol. Rep. 2019, 41, 1560-1574. [CrossRef]

114. Patibandla, J.R.; Fehniger, J.E.; Levine, D.A.; Jelinic, P. Small cell cancers of the female genital tract: Molecular and clinical aspects. Gynecol. Oncol. 2018, 149, 420-427. [CrossRef]

115. Cui, B.; Zheng, B.; Zhang, X.; Stendahl, U.; Andersson, S.; Wallin, K.L. Mutation of PIK3CA: Possible risk factor for cervical carcinogenesis in older women. Int. J. Oncol. 2009, 34, 409-416.

116. Lachkar, B.; Minaguchi, T.; Akiyama, A.; Liu, S.; Zhang, S.; Xu, C.; Shikama, A.; Tasaka, N.; Sakurai, M.; Nakao, S.; et al. Prognostic significance of PIK3CA mutation in stage IIB to IVA cervical cancers treated by concurrent chemoradiotherapy with weekly cisplatin. Medicine 2018, 97, e11392. [CrossRef] 
117. Zieba, S.; Kowalik, A.; Zalewski, K.; Rusetska, N.; Goryca, K.; Piascik, A.; Misiek, M.; Bakula-Zalewska, E.; Kopczynski, J.; Kowalski, K.; et al. Somatic mutation profiling of vulvar cancer: Exploring therapeutic targets. Gynecol. Oncol. 2018, 150, 552-561. [CrossRef]

118. Ousati Ashtiani, Z.; Mehrsai, A.R.; Pourmand, M.R.; Pourmand, G.R. High Resolution Melting Analysis for Rapid Detection of PIK3CA Gene Mutations in Bladder Cancer: A Mutated Target for Cancer Therapy. Urol. J. 2018, 15, 26-31. [CrossRef]

119. Arjumand, W.; Merry, C.D.; Wang, C.; Saba, E.; McIntyre, J.B.; Fang, S.; Kornaga, E.; Ghatage, P.; Doll, C.M.; Lees-Miller, S.P. Phosphatidyl inositol-3 kinase (PIK3CA) E545K mutation confers cisplatin resistance and a migratory phenotype in cervical cancer cells. Oncotarget 2016, 7, 82424-82439. [CrossRef]

120. Li, X.; Dai, D.; Chen, B.; Tang, H.; Xie, X.; Wei, W. Efficacy of PI3K/AKT/mTOR pathway inhibitors for the treatment of advanced solid cancers: A literature-based meta-analysis of 46 randomised control trials. PLOS ONE 2018, 13, e0192464. [CrossRef]

121. Jehan, Z.; Bavi, P.; Sultana, M.; Abubaker, J.; Bu, R.; Hussain, A.; Alsbeih, G.; Al-Sanea, N.; Abduljabbar, A.; Ashari, L.H.; et al. Frequent PIK3CA gene amplification and its clinical significance in colorectal cancer. J. Pathol. 2009, 219, 337-346. [CrossRef]

122. La Monica, S.; Galetti, M.; Alfieri, R.R.; Cavazzoni, A.; Ardizzoni, A.; Tiseo, M.; Capelletti, M.; Goldoni, M.; Tagliaferri, S.; Mutti, A.; et al. Everolimus restores gefitinib sensitivity in resistant non-small cell lung cancer cell lines. Biochem. Pharmacol. 2009, 78, 460-468. [CrossRef]

123. Madsen, R.R.; Vanhaesebroeck, B.; Semple, R.K. Cancer-Associated PIK3CA Mutations in Overgrowth Disorders. Trends Mol. Med. 2018, 24, 856-870. [CrossRef] [PubMed]

124. Keppler-Noreuil, K.M.; Sapp, J.C.; Lindhurst, M.J.; Parker, V.E.; Blumhorst, C.; Darling, T.; Tosi, L.L.; Huson, S.M.; Whitehouse, R.W.; Jakkula, E.; et al. Clinical delineation and natural history of the PIK3CArelated overgrowth spectrum. Am. J. Med. Genet. A 2014, 164a, 1713-1733. [CrossRef]

125. Lawrence, M.S.; Stojanov, P.; Mermel, C.H.; Robinson, J.T.; Garraway, L.A.; Golub, T.R.; Meyerson, M.; Gabriel, S.B.; Lander, E.S.; Getz, G. Discovery and saturation analysis of cancer genes across 21 tumour types. Nature 2014, 505, 495-501. [CrossRef]

126. Kandoth, C.; McLellan, M.D.; Vandin, F.; Ye, K.; Niu, B.; Lu, C.; Xie, M.; Zhang, Q.; McMichael, J.F.; Wyczalkowski, M.A.; et al. Mutational landscape and significance across 12 major cancer types. Nature 2013, 502, 333-339. [CrossRef]

127. Millis, S.Z.; Ikeda, S.; Reddy, S.; Gatalica, Z.; Kurzrock, R. Landscape of Phosphatidylinositol-3-Kinase Pathway Alterations Across 19784 Diverse Solid Tumors. JAMA Oncol. 2016, 2, 1565-1573. [CrossRef]

128. Semple, R.K.; Vanhaesebroeck, B. Lessons for cancer drug treatment from tackling a non-cancerous overgrowth syndrome. Nature 2018, 558, 523-525. [CrossRef] 